\title{
Operational strategies influencing small and medium enterprises (SMEs) into creative economy businesses
}

\author{
Pisit Potjanajaruwit ${ }^{1, *}$ \\ ${ }^{1}$ Suan Sunandha Rajabhat University, Thailand
}

\begin{abstract}
This research aimed to test the relationship and impact of operational strategies that influence the development of small and medium enterprises (SMEs) into creative economy businesses by using questionnaires as a tool for collecting data from 196 Thai SMEs entrepreneurs. The statistics used for data analysis were multiple correlation analysis. Furthermore, multiple regression analysis. The research results were found that (1) the operational strategies of knowledge, education, creativity, and modern technology and innovation have a positive relationship and impact on the development of small and medium enterprises. (SMEs) to be a creative economy as a whole. When considering each aspect, it was found that knowledge, education, and creativity are parts of the use of intellectual property linked to cultural background and modern technology and innovation had a significant positive relationship and impact on developing small and medium enterprises (SMEs) to be creative economy businesses at the 0.05 level.
\end{abstract}

\section{Introduction}

Creative Economy construct or creative economy it is the concept of the country to form prosperity and economic stability ceaselessly by making new products and services about infrastructure and cultural heritage. Creative thinking and social knowledge of the Kingdom of Thailand that has been accumulated for an extended time within the development of developed countries the main target is on this idea significantly. This will be seen from the rise of the inventive trade. As an example, within the European Community, America, Japan, and Chosen for the definition of creative economy, the United Nations Conference on Trade associate degreed Development (UNCTAD) defines it as an economy that reflects a method that integrates culture, economy, and technology into the along and in line with the present atmosphere, the inventive Economy stands out among the standard industrial production systems and agriculture [1].

The business opportunities are not limited to specific industry groups. Entrepreneurs in every industry can apply creative economic ideas to the benefits of their business. With research and development investment and government support contributing to the promotion of creative economic concepts - the development of essential utilities in

* Corresponding authors: pisit.po@ssru.ac.th 
communication, intellectual property systems, and legal requirements. Open up creative space and drive entrepreneurship cooperation Government and education sectors and the preparation of potential and readiness to open up business opportunities after ASEAN negotiations $[2,3]$.

SMEs tend to overgrow due to New marketing has contributed to a strong way of conducting specialized business due to its capital advantage. The company has a technology and production size that saves from using the production capacity and technology available to the fullest.

Causes of business growth SMEs in the economy, the advancement of technology enables small and medium-sized enterprises to operate certain types of businesses and distribute products to consumers thoroughly and meet the needs of customers with the flexibility of small and medium enterprises. As a result, it is easy to enter the international market efficiently and successfully, and with telecommunications communications able to connect the world closer to each other. Many small and medium-sized enterprises can quickly enter international businesses [4].

Table 1. Characteristics of the Creative Economy.

\begin{tabular}{|l|l|}
\hline \multicolumn{1}{|c|}{$\begin{array}{c}\text { Characteristics of the } \\
\text { Creative Economy }\end{array}$} & \multicolumn{1}{c|}{ Positive impact on SMEs and the economy } \\
\hline $\begin{array}{l}\text { 1. The use of intellectual } \\
\text { property linked to local cultural } \\
\text { fundamentals }\end{array}$ & $\begin{array}{l}\text { 1. Creativity" is created to "add value" as well as "create new } \\
\text { value" for the products and services of SMEs businesses } \\
\text { based on "unique capabilities." }\end{array}$ \\
\hline $\begin{array}{l}\text { 2. Technology is applied to } \\
\text { local wisdom in the } \\
\text { development of local products } \\
\text { and services. }\end{array}$ & \begin{tabular}{l} 
2. Inspire business to sustainably with the world. \\
\hline
\end{tabular} \\
\hline $\begin{array}{l}\text { 3. From government support to promote the concept of the } \\
\text { creative economy, whether it is infrastructure development. } \\
\text { According to the requirements of the law, an intellectual } \\
\text { property communication system creates and promotes } \\
\text { cooperation between patients. Government and government. }\end{array}$ \\
\hline
\end{tabular}

Based on the above reasons, the researcher is interested in analyzing the operational strategies influencing small and medium enterprises (SMEs) into creative economy businesses. The research results can be used to improve the process of operations to ensure that SMEs have the opportunity to succeed.

\section{Methodology}

Research on operational strategies that influence small and medium enterprises (SMEs) into creative economy businesses. The researcher has followed the methodology following steps: Population and Sampling, Research tool development, Data analysis.

\subsection{Population and Sampling}

The population used in the research is the entrepreneurs of SMEs in Thailand for 391 who registered with the Department of Business Development and samples used in the research, namely 196 SMEs registered with the Department of Business Development, with the opening of Krejcie and Morgan tables [5] and stratified random sampling method will provide [6]. 


\subsection{Research tool development}

The tools used in this research are questionnaires created according to the objectives and conceptual frameworks established by the creation and development of the instruments. The researchers took the following steps: Studies on the analysis of operational strategy relationships influencing the development of small and medium enterprises (SMEs) into creative economic businesses, creative economies of SMEs from documents, textbooks, related research articles, and seek advice from qualified experts to guide the conceptual framework. The survey was conducted in a trial (try-out) with 30 non-sample SMEs and then tested the instrument's reliability by analyzing the reliability. The alpha coefficient is based on Cronbach's approach, whose operational strategy influences the development of small and medium enterprises (SMEs) with an alpha coefficient of between 0.6639 0.9462 .

\subsection{Data Analysis}

The researchers analyzed the data gathered from the questionnaire using a SPSS computer program and tested the relationship and impact of the operational strategy factors affecting the development of small and medium-sized enterprises (SMEs) into the creative economic business of SMEs in Thailand using multiple correlation analysis and multiple regression correlation analysis and using the reliability statistics of test by the Alpha -Correlation Method.

\section{Results}

According to Tab. 2 found the impact of entrepreneurs' opinions on the overall creative economy is higher $(\bar{X}=3.99)$ when considering a particular aspect at the high level, the meanings from the top three were ranked as follows: Education $(\bar{X}=4.14)$ on the use of intellectual property linked to the cultural background $(\bar{X}=4.00)$ and technology and innovation $(\bar{X}=3.98)$ After that, the researchers analyzed the correlation of operational, strategic factors influencing the development of small and medium enterprises (SMEs) as a creative economy as a overall it found that

The independent variables are related as an over all which may cause problems with multicollinearity, so the researcher was tested multicollinearity using VIF shows that the VIF value of the independent variable creative economy factors ranges from 2.490-4.502. It shows that the independent variables are not correlated, thus not a problem because of the independent variables' internal relationship. This is consistent with [7].

Table 2. The overall of opinions on the factors of creative economic operating strategy of SME in Thailand.

\begin{tabular}{|l|c|c|c|}
\hline \multicolumn{1}{|c|}{ Creative Economy Operating Factors } & $\bar{X}$ & S.D. & Results \\
\hline 1. Knowledge & 3.97 & 0.56 & High \\
\hline 2. Education & 4.14 & 0.49 & High \\
\hline 3. Creative & 3.94 & 0.45 & High \\
\hline 4. The use of intellectual property linked to cultural fundamentals & 4.00 & 0.52 & High \\
\hline 5. Professional expertise & 3.92 & 0.45 & High \\
\hline 6. Technology and Innovation & 3.98 & 0.46 & High \\
\hline \multicolumn{1}{|c|}{ Overall } & 3.99 & 0.42 & High \\
\hline
\end{tabular}


Table 3. The correlation analysis of creative economy factors and the overall business development of SMEs entrepreneurs.

\begin{tabular}{|c|c|c|c|c|c|c|c|c|}
\hline Variables & $\begin{array}{c}\text { DE } \\
\text { CO }\end{array}$ & KM & ED & CR & IC & WI & TI & VIF \\
\hline $\bar{X}$ & 3.99 & 3.97 & 4.14 & 3.94 & 4.00 & 3.99 & 3.99 & \\
\hline S.D. & 0.40 & 0.56 & 0.49 & 0.45 & 0.52 & 0.45 & 0.46 & \\
\hline DECO & & 0.641 & 0.771 & 0.775 & 0.736 & 0.754 & 0.76 & 2.62 \\
\hline KM & & & 0.551 & 0.554 & 0.775 & 0.555 & 0.689 & 2.49 \\
\hline ED & & & & 0.682 & 0.689 & 0.718 & 0.688 & 3.02 \\
\hline CR & & & & & 0.728 & 0.761 & 0.727 & 4.50 \\
\hline IC & & & & & & 0.700 & 0.802 & 3.48 \\
\hline WI & & & & & & & 0.780 & 4.03 \\
\hline TI & & & & & & & & 5 \\
\hline
\end{tabular}

*Statistical significance at the level of 0.05 .

When considering the correlation coefficient between each independent variable and the dependent variable. It was found that the independent variable was positively correlated with the dependent variable, with a correlation coefficient of $0.551-0.780$ being statistically significant at level 0.05 . The researcher then analyzed multiple regression.

From Tab. 4 it was found that the factors of the creative economy operating factors $(\mathrm{KM})$, education (ED), creativity (CR), and technology and innovation (IT) have a positive relationship with the developed small and medium enterprises (SMEs) to be a creative economy business (DECO) with statistical significance at the 0.05 level.

Therefore, the research hypothesis was accepted. For strategic factors, the use of intellectual property linked to cultural foundations (IC) and professional expertise (WI) has no relationship.

Table 4. The multiple regression analysis by using dependent variables of the creative economy operating factors approach.

\begin{tabular}{|c|c|c|c|}
\hline \multirow{2}{*}{ Independent Variables } & \multicolumn{2}{|c|}{ Creative Economy Operating Factors } & \multirow{2}{*}{ p-value } \\
\hline & Regression coefficient & Standard error & \\
\hline 1. Knowledge & 0.104 & 0.042 & $0.014^{*}$ \\
\hline 2. Education & 0.254 & 0.047 & $0.000 *$ \\
\hline 3. Creative & 0.258 & 0.057 & $0.000^{*}$ \\
\hline $\begin{array}{l}\text { 4. The use of intellectual } \\
\text { property linked to cultural } \\
\text { fundamentals }\end{array}$ & 1.528 & 0.059 & $0.979 *$ \\
\hline 5. Professional expertise & 0.105 & 0.060 & 0.081 \\
\hline $\begin{array}{l}\text { 6. Technology and } \\
\text { Innovation }\end{array}$ & 0.129 & 0.064 & $0.044^{*}$ \\
\hline
\end{tabular}

* Statistical significance at the level of 0.05 .

The results of multiple regression analyze showed that the factors of the operating strategy aspects (KM), education (ED), creativity (CR), and technology and innovation (TI) are predictors of the overall business development approach (DECO), so the researcher creates the forecasting equation. Doing a new multiple regression analysis consists of the above variables, with the multiple correlation coefficient of the dependent variable (R) equal to 0.866, the adjustment forecast coefficient (Adjusted R2) of 0.745, and the standard error. (SEest) equal to 0.203 , the forecast equation can be written as follows: 


$$
\mathrm{DECO}=0.599+0.102 \mathrm{KM}+0.277 \mathrm{ED}+0.293 \mathrm{CR}+0.172 \mathrm{IT}
$$

\section{Discussion}

The research on operational strategies influencing small and medium enterprises (SMEs) into creative economy businesses can be discussed as follows.

Entrepreneurs also have opinions on operating strategies that influence the development of small and medium enterprises (SMEs) into a creative economy as a whole. Moreover, it is on every side. It is at a high level because the creative economy is a model of it as the engine of the modern economy of developed countries that emphasize cultural heritage production and service. Creative work in print media or design services and other services related to information, digital, and creativity generate more revenue for developed countries than the production of products or services that focus on delivery. Issued by-products or services in their original form until being used as a model for countries worldwide, including Thailand, which has designated the creative economy as one of the key policies in driving the country into an era of competitive capital, knowledge and information technology [8].

This is consistent with the study of [9] it was found that the growth processes and the origin of growth of East Asian countries have changed significantly. Especially in the middle- to high-income countries, growth has been seen to increase due to the country's strength of cultural activity. This is not due to the accumulation of factors as in the past, which results from the study found that innovative activities, especially the service sector and the creative economy, are gaining importance from the high-tech or developed countries that develop the creative economy Influenced and supported by government and private initiatives leading to the growth and development of the country.

For the creative economy operating strategy factors, it has a positive relationship with the development of small and medium enterprises (SMEs) to be a creative economy overall business in terms of strategic planning, that is, business operations to be efficient and effective arise from the accumulation of Knowing the inside of the person arising from that person's learning until it is a concept. It is the principles and methods that can be used in planning the operations to be driven. Strategic planning is a decision-making process that is used as a guideline for business development to determine the future direction of an organization by defining the conditions. A strategic plan is critical to the relationship of the changing environment opportunities and obstacles to the potential for the future. These are the strengths and weaknesses of the agency for the strategic formulation of the agency, if the environment changes, the strategy must be adapted.

This is consistent with the concept of [10] explains innovation is doing things in new ways, and it can also mean changes in thinking, production, process, or organization, whether the change is due to development, extension, change. It is believed to change applications or processes, and in many fields, it is believed that for something innovative it has to be new. Moreover, the newness must add value to things as well. The goal of innovation is to make positive changes to make things change for the better. Innovation brings more productivity and is a crucial source of innovation. National economic and social security.

Therefore, entrepreneurs should pay more attention to the creative economy, including knowledge, education, creativity, intellectual property utilization that is linked to the cultural foundation, knowledge accumulation of society. Moreover, the technology and innovation to be applied in business development to create commercial advantage and should focus on promoting continuous business development in terms of strategic planning, marketing, production, management and technology to strengthen the organization's 
strength and sustainability and apply creative economy principles to business development in order to increase the organizational potential and reduce business constraints.

\section{References}

1. W. Wattanacharoensil, M. Schuckert, Current Issues in Tourism 19(10), 1045-1070 (2016)

2. B. Moriset, Building new places of the creative economy. The rise of coworking spaces (2013)

3. I. Onyusheva, Polish J. of Management Studies 16(2), 198-209 (2017)

4. P. Pholphirul, Creative Economy and Development Issues in Thailand 7(1) (2013)

5. W. Boonsatorn, Create passion for Thailand toward creative economy 7(1), 307-307 (2013)

6. H.T. Van et al., Intern. J. of Energy Economics and Policy 8(4), 21-27 (2018)

7. M. Budhi et al., Management Science Letters 10(10), 2301-2310 (2020)

8. A. Aishaa et al., International Journal of Business 24(4), 369-392 (2019)

9. D. Ushakov et al., Intern. J. of Ecological Economics and Statistics 38(4), 164-172 (2017)

10. E. Munro, Poetics 64, 14-25 (2017) 